\title{
DIVERSIFICATION IN BANKING INDUSTRY- A REVIEW
}

\author{
Shital Mittal \\ Customer Support Operations Specialist, SAP Ariba, U.S.A. \\ Research Scholar, GITAM (Deemed to be University), Visakhapatnam, \\ Andhra Pradesh, India \\ Dr. K Lubza Nihar \\ Program Chair, MBA Programs, Associate Professor, Accounting and Finance, \\ GITAM Institute of Management, Visakhapatnam, Andhra Pradesh, India
}

\begin{abstract}
This paper reviews the existing literature on Diversification in the Banking Industry, globally and in the Indian Context. The main objective is to review and present different viewpoints and findings of various studies to identify possible research gaps. The paper is divided into two sections - diversification as a strategy; and Diversification in Indian Banking Industry. After a comprehensive review the paper presents the possible research areas that can be explored by future researchers.
\end{abstract}

JEL Classification: G21, G21, G28, G32, C23, L25.

Key words: Income Diversification, Non-Interest Income, Sectoral Diversification, Indian Banking Industry

Cite this Article: Shital Mittal and K Lubza Nihar, Diversification in Banking IndustryA Review, International Journal of Management (IJM), 11(12), 2020, pp. 3104-3116. http://iaeme.com/Home/issue/IJM?Volume=11\&Issue $=12$

\section{INTRODUCTION}

Every organization works towards maximizing shareholder wealth. The investment alternatives and strategic decisions are aligned in this direction. One such strategic decision is diversification. There are various ways to diversify but this paper seeks to look at diversification specific to banking industry. In response to the global economic and financial sector reforms, the banking industry has become highly competitive. Deregulation has permitted financial institutions to move to non-interest sources of income and technological advancement has made it easier for banks to diversify.

The priority sector lending norms, transparency and disclosures required by accounting and audit regulations, declining interest margins in the recent past in the traditional banking activities (Gambacorta, 2014) and reduced market share may be the key reasons for banks to 
look at alternative income generation avenues and not depend only on traditional business operations. Traditional activities of banks like investing in loans and advances involve default risk and may impact bank earnings, as Non-Performing Assets (NPAs) pile up on the bank's balance sheet. This issue is prominent in the case of priority sector advances by Public Sector Banks, in the developing economies like India. India's financial sector like most other developing economies is considered un-stable, with unpredictable interest rates, inefficiencies in the intermediation process, and is a high-risk investment (Shawn, 2002).

The differences in the level and type of diversification depends on income sources, ownership structure, and liquidity of a bank and also on the basis of the level of financial liberalization of an economy. Diversification, as a decision is important not only for maximizing wealth of shareholders but also to sustain its business and retain customer confidence. Customers can have a run on the bank, if they lose confidence in the bank. This situation can adversely affect the banks operations and its profitability. BASEL III has put in place stringent Capital Adequacy Requirement, so that banks are able to use buffer resources in case of financial distress or crisis within the organization or caused by external factors. All these have squeezed the margins available for banks.

These reasons may have created a need for banks to look for alternative avenues to generate income. The alternative sources of income are fee income, service charges, trading fee/income, forex income etc. Portfolio asset allocation is another crucial decision for Banks. The banks look at the portfolio theory of investment and invest in different assets. They rank the options on the basis of desirability of the trade-off, of risk and return. Modern portfolio theory claims that diversification into non-correlated or negatively correlated activities reduces the overall risk of the portfolio (Markowitz H. , 1952). Applying this theory, if Interest Income is negatively correlated with Non-Interest Income, then it leads to lower risk and higher returns. This effect is possible because of income diversification.

With this thought, the paper reviews available literature in the area of Bank Diversification.

\section{REVIEW OF LITERATURE}

\subsection{Diversification as a Strategy}

The review of available literature is for a period of 20 years and it is found that researchers from different countries, have studied different aspects of diversification. There are various reasons for diversification. Review of literature suggests that economies of scale due to diversification is supposed to improve profits as (Teece, 1982) banks are driven by BASEL norms and engage in tested risk management techniques and procedures. Diversification may be opted by banks as they give a higher competitive advantage (Bodnar, 1999), decrease financial intermediation cost (Diamond, 1984) (Morris, 2001) and result in better resource allocation (Stein, 1999). Resource allocation is not limited to financial resources but includes managerial efficiencies (Bodnar, 1999; Iskandar-Datta \& McLaughlin, 2007) (Choi \& Kotrozo, 2006) and information sharing between different divisions of banks (Diamond, 1984) (Stein, 1999) (Rajan, 2000). These efficiencies will help banks to deepen and broaden the market by cross-selling products like loans, financial services, sale of securities, insurance, mutual fund services and other activities. This leads to benefits of economies of scale and improved key performance indicators. The literature suggests that there are many reasons and resultant benefits of diversification. Research studies that encompass the banking industry landscape especially in emerging economies has found less focus.

Diversification as a concept is researched and so are the opportunities and challenges. Few studies that supports diversification are (Hayden, Porath, \& Westernhagen, 2007; Rossi, 2009; Markowitz H. , 1959; Bebczuk \& Galindo, 2011). Basel Committee on Banking Supervision also acknowledges that the banking crisis in the past few decades was caused mostly by the 
concentration of bank assets and lack of diversification (Busch \& Kick, 2009). Some regulatory requirements for Banks require diversification, thus it also factors in as a reason, in some cases (Acharya \& Saunders, 2006). Diversification aims at reduction of risk and leverage with an objective to ultimately improve banks performance.

There are studies that do not favour diversification. They have found that the damages caused by diversification outweigh benefits when there are issues related to competency of the managerial level (Harris, 1982) (Meyer, 1992), monitoring the output of diversification. There are issues of stakeholders' conflict that results in higher agency cost (Rajan, 2000). Sometimes diversification involves transcending national boundaries that increases complexity of operations and legal issues as they enter unchartered territories causing increased cost (DeYoung \& Roland, 2001; Stiroh K. J., 2004a). The review of literature highlights that the benefits of economies of scale/scope exist only to a point. Such that, performance and the benefits of diversification would be an inverted- $U$ shape, meaning that beyond an optimal level of diversification the benefits would decline and may ultimately become negative. This could be due to the costs associated with a firm's increased complexity, may surpass the benefits of diversification. Increased competition is making diversification unappealing in some situations (Tabak, Fazio, \& Cajueiro, 2011). Diversification can be achieved by rebalancing sources of income, geographical boundaries, and sectors.

\subsection{Diversification in the Banking Industry}

When banks earn a higher proportion of the earnings from non - traditional sources they are said to engage in Income Diversification. The literature review has shown that the nontraditional sources are known as Other Income, Fee Income, other Operating Income but the nomenclature mostly used to denote them is Non-Interest Income (Hayden, Porath, \& Westernhagen, 2007).

The sustainability of the firm depends on its capabilities to earn income through its true operations. Other incomes may increase profits but may hit the core operation of the bank causing irregularity in bank earnings through core operations. Alternative income requires the bank to recruit the managerial cadre with the required skill set. This may increase cost of operations that may not commensurate the income earned which may in turn impact performance. As per (Busch \& Kick, 2009) when banks engage in income diversification there is a possibility of shift of customer loyalty thus banks fee-based revenues might be more unpredictable. Traditional services are more customer centric and may not shift to other banks easily. Third is that non-Interest Income source requires less regulatory capital, leading to higher degree of risk taken by banks, thus banks tend to have unstable earnings.

Earlier research used portfolio theory to examine the relationship between diversification into non-traditional banking activities and reduction in bank risk. There are mixed results. The study on the validity of the aforementioned scenario was tested in the context of US banking and the results shows no relationship between diversification into non-traditional banking activities and reduction in bank risk (Wall, 1987). (Kwast, 1989) found potential for gains from diversification of bank's securities and non-securities activity. Same was found by (Gallo, Apilado, \& Kolari, 1996) that diversifying increases the profitability of the banks, along with reducing the systematic industry risk by taking diversification into mutual fund activities. When the recent literature on income diversification is reviewed there is more evidence to suggest that non-interest generating activities are not beneficial, nor do they reduce risk. This has been said in the studies by (DeYoung \& Roland, 2001) (Stiroh K. J., 2004a) (De Young \& Rice, 2004) (Stiroh \& Rumble, 2006) (Hirtle \& Stiroh, 2007). Their studies show empirical evidence that large US Banks dependence on fee based activities leads to instability in revenues. US commercial banks, generated $20 \%$ of operating income from non-interest sources in 1980 , 
compared to $32 \%$ in 1990 and $42 \%$ in 2004, according to (De Young \& Rice, 2004). Reason for contradictory results by researchers conducting studies may be the different time periods studied. (Limei Sun, Zhu, \& Stephenson, 2017) study finds that there is a negative relationship between fee-based Income and performance of banks in China.

Banks in developed countries like USA have higher levels of diversification as per the research by (Hirtle \& Stiroh, 2007), which is leading to increased instability. This may be the reason for the acceleration in the shift of focus from non-traditional activities to traditional activities. Banks now are working more towards stability of returns that offset's volatility in non-retail business. Also (De Young \& Rice, 2004) found that well managed US commercial banks were less engaged in fee based activities, when calculated by relative ROE; whereas large banks with core relationship banking were much more dependent on fee based income. The study also finds that higher profits were linked with relatively lower increases in Non-Interest Income, more unpredictable profits and on overall, a decline of risk-return trade off. In the studies by (Demirgüc-Kunt, 2010) (Altunbas, 2011), the higher income diversification due to fee based income increases risk. These studies focused on banks which have more business focused on Investment and are listed banks, than unlisted banks. But on increasing the number of banks used in the study the results considerably change (Huizinga, 2010).

On the contrary some studies, (Stiroh K. J., 2004a) show considerably positive influence of income diversification on earnings especially smaller banks, when they shift their focus to nonInterest Income generating activities, are able to perform better. (Davis, 2000) gave the same conclusion for some European and German Banks (Köhler M. , 2012) showing significant benefits from Income Diversification predominantly, for smaller banks, in contrast to larger banks. (Smith, 2003) says that, by income diversification European banks are able to achieve better benefits in revenue and also found a negative correlation between the Non-Interest Income and Interest Income, unlike (DeYoung \& Roland, 2001). Whereas (Chiorazzo, Milani, \& Salvini, 2008), studied relationship between profitability in Italian Banks and Non-Interest Income. They found evidence that income diversification has a positive relationship with risk adjusted returns and it increased with higher diversification, predominantly in the case of large banks. Banks showed substantial high risk-adjusted returns when there was an increase in income from non-traditional banking activities like fee based activities and these activities are positively related with risk adjusted Return on Equity and Total Assets (Busch \& Kick, 2009).

Banks with retail-focused business are considerably more stable if the share of fee based activities is increased (Köhler M. , 2013). These studies found that fee-based activities enable the bank to stabilize their earnings and minimize risk. The savings and commercial banks with attention on fee business can charge lower interest margins as their credit risk is controlled (Busch \& Kick, 2009). In the study by (Gambacorta, 2014), it was said that bank profitability and Income Diversification are positively related. These findings cannot be generalised as the literature review suggests that impact of income diversification on banks financial performance differs based on the economies where the banks are situated. (Chiorazzo, Milani, \& Salvini, 2008), (Smith, 2003) and (Baele, de, \& Vennet, 2007) show that risk-return trade-off for European banks increases with income diversification. Whereas the risk-return balance for USA deteriorates with income diversification (DeYoung \& Roland, 2001) (Stiroh K. J., 2004a) (De Young \& Rice, 2004) (Stiroh \& Rumble, 2006) (Hirtle \& Stiroh, 2007).

The banking industry, in general has seen, surprising level of geographic development, through expansion of branch network, mergers and acquisitions (Bandelj, 2016), due to the ever changing technological, financial and economic landscape.

As per (Berger, DeYoung, R., \& Udell, 2000) diversification by way of acquisitions and mergers, lead to higher profitability and greater economic performance in comparison with diversification by income sources. A study by (Alessandrini \& Zazzaro, 2005), show that when 
there was a substantial economic difference between the branches at various geographical locations and the bank with higher diversification showed higher risk-adjusted performance. The study by (Deng \& Elyasiani, 2008), identifies that increasing distance between branches and headquarters, through geographical diversification increases valuation and reduces risk, but the benefits diminished with increasing distance.

Studies on Italian banks, (Cotugno \& Stefanelli, 2010) showed high positive correlation between geographical diversification and higher stability and bank profitability. But problems arising due to region specific diversity, lead to agency problem as per studies by (Rajan, 2000), further causing organizational incompetence. This may lead to diversified banks being affected by hostile market valuations.

While documenting the geographical diversification trends for US banks since 1994, (Miller \& Parkhe, 2002) said 'Geographical diversification increased exchange risk and political risks, calling it liability of foreignness'. The increase in costs and revenue arise in the global scenario, due to the changing banking operating environments, financial markets and credit. Similarly (Morgan \& Samolyk, 2003) there was a significant increase in the lending capability of the banking system as a whole, though geographic diversification did not have any evident impact on risk reduction or profits. (Hayden, Porath, \& Westernhagen, 2007) suggested that geographical diversification led to bank's returns declining and no change in banks profitability, even after adjusting for the risk.

Banks with bigger asset allocation in emerging markets showed higher risk-adjusted returns, in studies by (García-Herrero \& Vázquez, 2013). For banks with international allocation assets across geographies, substantial home bias was also found, which means Banks tend to invest more in the home country, even though investing in other countries and diversifying is beneficial. (Bandelj, 2016) analyzed European banks and results show that due to agency problems the cost of equity is high for banks which are geographically diversified.

The US-based foreign banks when compared with the domestic banks had higher productivity, as per studies of (Berger \& Deyoung, 2001) but while evaluating the usefulness of cross-border relations of financial institutions, the productivity of domestic banks was found to be greater than foreign banks for other countries, like Germany, UK, France and Spain. Though empirical studies across different countries/geographies have given contradictory results about geographical diversification, its optimal degree etc. So it's necessary to understand the implications for the firms to define what amount of geographical diversification is appropriate for them.

The Diversification into different sectors is measured/called Sectoral diversification, Loan Diversification or Priority Sector Diversification, like in India. Priority Sector Lending in many countries is also referred to as Directed Lending Program. According to reports by (Samson \& Bayat, 1989) (Vittas \& Cho, 1995), the Direct Lending Program was successful to the economy. There are many such studies on Priority Sector Lending but these studies do not study it as per the Banking Industry risk-return and it's relation as a diversification measure for the Bank. Whereas the concentration of research in Indian Banking Industry is concentrated on relation between Priority Sector Lending and Non-Performing Bank Assets.

There are very few research on Sectoral/Loan Diversification by researcher's (Acharya \& Saunders, 2006; Chen, Wei, Zhang, \& Shi, 2013; Langrin, 2009; Berger A. N., 2010; Shameem, Kumar, Subhash, \& Vinod, 2015; Busch \& Kick, 2009), in the past by making a comparison between loan diversification to different sectors of an Industry and its relationship between banks' risk-return. The study by (Busch \& Kick, 2009), use diversification of Banks Loan Portfolio into nine sectors. As per the studies by (Diamond, 1984) (Acharya \& Saunders, 2006) (Shameem, Kumar, Subhash, \& Vinod, 2015), relationship between bank risk and diversification (concentration) of loan and advances, shows a negative relationship, thus 
reducing risk. Therefore it's better for the Banks to provide loans and advances to various sectors of the industry. But the research also showed that after a point, the diversification in the loan portfolio follows an inverted U-shape as mentioned before because of increased cost and complexity, thus overshadowing the profits (Acharya \& Saunders, 2006) (Chiorazzo, Milani, \& Salvini, 2008).

\subsection{Diversification in the Indian Banking Industry}

In this section we will look at the studies related to Diversification, in context of the Indian Banking Industry. We study the findings of various available research literature in the context of understanding the effects of Income Diversification, Geographic Diversification and Sectoral diversification of loan and advances on risk and return of Indian Scheduled commercial banks.

India's financial system is largely dependent on the banking system for financial intermediation unlike market-based economy where the equity markets play a leading role in financial resource mobilization. Indian banking sector is also characterized by entry restriction, due to strict regulatory guidelines from the RBI, which requires Banks to lend to priority sector. Diversification in the Indian banking industry is at a nascent stage as compared with the developed countries like US, Germany and other European nations. Largest private sector bank ICICI Bank entered in to credit card business and gave a tough challenge to its competitors like Kotak Mahindra Bank and Citibank. It undertook extensive cross-selling of products resulting significant growth of their entire business. The largest public sector bank SBI in the Indian Banking Industry, started its insurance division through SBI life in 2010. Mutual fund tie-ups and bancassurance are other areas of diversification of Public sector banks. (Khandelwal, 2006).

Private Sector Banks in India have higher Non-Interest Income proportion (as seen in Table 2) and Income Diversification, when compared with the Public Sector Banks (Bapat \& Sagar, 2016) (Pennathur, Subrahmanyam, \& Vishwasrao, 2012),. (Gupta \& Singh, 2014) included foreign banks in their study and concluded that Public Sector Banks are relatively low on income diversification when compared with foreign banks and private sector banks. Studies of (Ghosh, 2011) (Gupta \& Singh, 2014) (Sharma \& Anand, 2019), related to Indian Banking Industry shows positive correlation between Banks Profitability and Diversification. Whereas studies of (Bapat D. , 2012) (Deb \& Sen, 2016) show negative correlation between Banks Profitability and Diversification. Studies by (Ghosh, 2011) involved four diversity parameters namely Asset Diversification (Fixed Assets, Cash, and balances with RBI), Sectoral Diversification (priority/public/private sector or banks), Fund Diversification (borrowings, deposits, equity and subordinated debt) and Income Diversification (investment trading income, commission income, forex trading income, interest income and other income) and the study shows that banks tend to be more profitable when their income streams are widely spread over different income sources.

Income Diversification levels of Indian Banks is comparatively lower than Global standards (Gupta \& Singh, 2014). The study found that Non-Interest Income as an income source was volatile, mainly the trading income caused most volatility in returns and profitability.

After the global financial crisis, as per the findings of (Bapat D. , 2012), the mean efficiencies, of PSB's, were higher than that of private sector banks when interest expenses and non-interest expenses were analysed. Similarly the study by (Pennathur, Subrahmanyam, \& Vishwasrao, 2012) said that public sector banks when related to, private banks generate lower fee income. The mean efficiency of public sector banks is greater than private sector banks (Bapat D. , 2012) (Pennathur, Subrahmanyam, \& Vishwasrao, 2012). In the study of Indian Banks by (Bapat \& Sagar, 2016) who used path coefficient with dependent variable as Return on Assets (ROA) and independent variables as 1) Ratio of Non-Interest Income to Interest Income (as a measure of Income Diversification), 2) Non-Performing Assets (NPA), and 3) 
profit per employee it found that there are significant difference in Diversification, based on Ownership but no significance for Size.

Regarding Diversification by Location of Banks, there exists evidently no consensus amongst researchers about the effects on returns and risks. Geographical diversification helps in increasing bank profits, due to banks' efficiency through economies of scale but does not have any substantial impact on bank risk as per (Sharma \& Anand, 2019), unlike studies by (Deb \& Sen, 2016), where diversification does not reduce banks risk or return. As per global diversification strategy, diversification increases profits but it's not true in case of India according to the research findings of the paper.

Loan Diversification/ Priority Sector Diversification, in Indian Banking measures Priority Sector's loans and advances. Which basically comprises of Agriculture, Micro, Small and Medium Enterprises, Export Credit, Education, Housing, Social Infrastructure and Renewable Energy (RBI, 2018). The research work in Indian Banking Industry is discussed next.

The sectoral diversification of advances and loans helped in decline of risk, as per studies by (Shameem, Kumar, Subhash, \& Vinod, 2015). It was found that banks with loans and advances spread across various sectors of the industry are less uncertain when related to banks focused in a particular sector. But (Vidyarthi, 2019) show that sectoral diversification at first positively impacts the bank profits, but after a point, it shows an inverted U-shaped relationship with banks returns and thus bank income start to weaken even after further increase in diversification.

As per the study by (Shameem, Kumar, Subhash, \& Vinod, 2015), the regulator RBI requires the Banks in India, to compulsory loans and advances to the Priority Sector at $40 \%$. Which leads to the lower overall Bank performance. This mandate was only for Public Sector Banks in the past but private sector Banks are supposed to meet the same limits (Rebello, 2016). Private Sector Banks are thus gradually increasing there share in the Priority Sector. Thus there is a need for further study, involving the classification of Ownership structure with current context and data pertaining to recent years.

Thus there is research done in the field of Income Diversification (Ghosh, 2011) (Gupta \& Singh, 2014), Geographical Diversification (Deb \& Sen, 2016; Sharma \& Anand, 2019) and Sectoral Diversification (Bhattacharya \& Dutta, 2016). Diversification has been studied extensively but very less research has been done in the recent past in India in the context of Banking Channels Diversification, Portfolio Diversification and Industry diversification. The scope of studies with respect to classification of Size and Ownership of Indian Scheduled Commercial Banks and the relationship with Diversification is close to non-existent. Thus there is a great need for study, to be done to see relationship of Diversification with Bank Ownership and Bank Size in Indian Banking Industry, for the recent past (Bapat D. ,2012), it's effect on risk and return of the Banks.

Table 1 List of Some Research Studies

\begin{tabular}{|c|c|c|c|c|}
\hline $\begin{array}{c}\text { Author, } \\
\text { Data Range }\end{array}$ & $\begin{array}{l}\text { Variable for } \\
\text { Diversification }\end{array}$ & $\begin{array}{c}\text { Other } \\
\text { Variables }\end{array}$ & Method & Findings \\
\hline $\begin{array}{l}\text { (Choi \& } \\
\text { Kotrozo, } \\
2006), \\
1995-2002\end{array}$ & $\begin{array}{l}\text { HHI } \\
\text { (Revenue } \\
\text { Div, NII } \\
\text { Div, \& loan } \\
\text { Div) }\end{array}$ & $\begin{array}{l}\text { ROA, Tobin's q, } \\
\text { Annualized stock } \\
\text { returns, Control:- } \\
\text { Mkt. vs. Bank, } \\
\text { moral hazard } \\
\text { index, bank } \\
\text { freedom, } \\
\text { concentration \& } \\
\text { Governance }\end{array}$ & $\begin{array}{l}\text { Multivariate tests, } \\
\text { Tests of non-linear } \\
\text { and cross products } \\
\text { models. Studentized } \\
\text { T-tests }\end{array}$ & $\begin{array}{l}\text { Benefit of Div } \\
\text { outweigh the cost. } \\
\text { Geographical Div is } \\
\text { likely to enhance } \\
\text { performance but } \\
\text { Activity Div is } \\
\text { likely to undermine } \\
\text { performance. }\end{array}$ \\
\hline
\end{tabular}




\begin{tabular}{|c|c|c|c|c|}
\hline $\begin{array}{l}\text { (Busch \& } \\
\text { Kick, 2009), } \\
\text { 1995-2007. }\end{array}$ & $\begin{array}{l}\text { HHI } \\
\text { (Sectoral } \\
\text { Div) and NII } \\
\text { / TI }\end{array}$ & \multirow{3}{*}{$\begin{array}{l}\text { RAROE \& } \\
\text { RAROA, } \\
\text { LogAssets, } \\
\text { NPA/Tot Loans } \\
\text { (Risk), } \\
\text { Assets Growth } \\
\text { Rate, Ratio of } \\
\text { Equity/TA } \\
\text { (Leverage) and } \\
\text { Ratio of Loans/ } \\
\text { TA . } \\
\text { (Dummy - Time or } \\
\text { Region or } \\
\text { Holding) }\end{array}$} & $\begin{array}{l}\text { Fixed-Effects Panel } \\
\text { model with regressors } \\
\text { lagged by } 1 \text { year and, } \\
\text { two-stage least } \\
\text { squares estimator }\end{array}$ & $\begin{array}{l}\text { Higher fee income } \\
\text { means more } \\
\text { favorable risk- } \\
\text { return profile, i.e. } \\
\text { higher RAROA \& } \\
\text { RAROE. }\end{array}$ \\
\hline $\begin{array}{l}\text { (Chiorazzo, } \\
\text { Milani, \& } \\
\text { Salvini, } \\
\text { 2008), } \\
\text { 1993-2003 }\end{array}$ & $\begin{array}{l}\text { HHI (NII \& } \\
\text { II) and } \\
\text { NII/TI }\end{array}$ & & $\begin{array}{l}\text { Panel Regressions, } \\
\text { Fixed Effect, Wald } \\
\text { Test, Likelihood Ratio } \\
\text { Test, }\end{array}$ & $\begin{array}{l}\text { Income Div \& } \\
\text { RAROA shows +ve } \\
\text { relation. Also } \\
\text { inverted U-shaped } \\
\text { relation bw profits } \\
\text { per unit of risk \& } \\
\text { bank size. }\end{array}$ \\
\hline $\begin{array}{l}\text { (Lepetit, Nys, } \\
\text { Rous, \& } \\
\text { Tarazi, 2007), } \\
1996-2002\end{array}$ & $\begin{array}{l}\text { Ratio of } \\
\text { NII/TI }\end{array}$ & & $\begin{array}{l}\text { Univariate mean tests, } \\
\text { Rank correlation test } \\
\text { Multivariate } \\
\text { Regression analysis }\end{array}$ & $\begin{array}{l}\text { Income Div causes } \\
\text { higher risk and } \\
\text { higher insolvency } \\
\text { risk. }\end{array}$ \\
\hline $\begin{array}{l}\text { (Gambacorta, } \\
\text { 2014), } \\
1994-2012\end{array}$ & $\begin{array}{l}\text { Ratio of } \\
\text { NII/TI and } \\
\text { NII/TI } 2\end{array}$ & $\begin{array}{l}\text { RAROA, } \\
\text { LogAssets, } \\
\text { Leverage, Loans to } \\
\text { deposit ratio, } \\
\text { Retail ratio } \\
\text { (customer loans } \\
\text { plus deposits/ TA } \\
\text { and deposit to total } \\
\text { funding ratio, } \\
\text { Bank \& Time FE, } \\
\text { Dummy -Country } \\
\text { *Time }\end{array}$ & $\begin{array}{l}\text { Non-Linear Approach, } \\
\mathrm{R}^{\wedge} 2 \text {, Econometric } \\
\text { Model. }\end{array}$ & $\begin{array}{l}\text { Income Div is } \\
\text { +vely correlated } \\
\text { with bank } \\
\text { profitability but } \\
\text { only up to } 30 \% \text { of } \\
\text { the Div ratio. }\end{array}$ \\
\hline $\begin{array}{l}\text { (Limei Sun, } \\
\text { Zhu, \& } \\
\text { Stephenson, } \\
\text { 2017), } \\
\text { 2007-2013 }\end{array}$ & $\begin{array}{l}\text { Ratio of } \\
\text { NII/TI }\end{array}$ & $\begin{array}{l}\text { ROE, Control - } \\
\text { CAR, NPA/Tot } \\
\text { Loans \& } \\
\text { Operating Cost / } \\
\text { Operating Income }\end{array}$ & $\begin{array}{l}\text { Panel Threshold } \\
\text { Model. }\end{array}$ & $\begin{array}{l}\text { NII is negatively } \\
\text { correlated with the } \\
\text { performance. }\end{array}$ \\
\hline $\begin{array}{l}\text { (Ghosh, } \\
\text { 2011), } \\
\text { 1997-2006 }\end{array}$ & $\begin{array}{l}\text { Four } \\
\text { Diversifica- } \\
\text { tion measure } \\
\text { by HHI i.e. } \\
\text { Asset, } \\
\text { Business } \\
\text { Line, Fund } \\
\text { \& Income. }\end{array}$ & $\begin{array}{l}\text { NII/Op. Inc, } \\
\text { Loan/Earnings } \\
\text { Asset, Ln Asset, } \\
\text { CAR, NPL, CIR }\end{array}$ & $\begin{array}{l}\text { Univariate } \\
\text { comparisons, } \\
\text { Multivariate } \\
\text { regression, Excess } \\
\text { Value and Tobin's q }\end{array}$ & $\begin{array}{l}\text { Banks are more } \\
\text { profitable when } \\
\text { Income Div is } \\
\text { more. The Asset } \\
\text { diversity, has no } \\
\text { impact on excess } \\
\text { asset valuation. }\end{array}$ \\
\hline $\begin{array}{l}\text { (Bapat \& } \\
\text { Sagar, 2016), } \\
\text { 2006-2013 }\end{array}$ & $\begin{array}{l}\text { Ratio of NII } \\
\text { / II }\end{array}$ & $\begin{array}{l}\text { PPE, ROA, NPA } \\
\& \text { CDR }\end{array}$ & $\begin{array}{l}\text { Two independent } \\
\text { sample t test, } \\
\text { Structural equation } \\
\text { modeling. Path } \\
\text { Coefficients. }\end{array}$ & $\begin{array}{l}\text { Significant } \\
\text { difference in } \\
\text { Diversification, } \\
\text { based on Ownership } \\
\text { but not Size. -ve } \\
\text { relation bw NPA \& } \\
\text { ROA. +ve relation } \\
\text { bw ROA \& Div }\end{array}$ \\
\hline
\end{tabular}

Diversification -Div, NII-Non-Interest Income (a.k.as Other Operating Income), II-Interest Income, Net II = Interest Income - Interest Expense, TI-Total Income, OI-Operating Income, Net OI = Net II + NNI, TA-Total Assets, ROA- Return on Assets, RAROA - Risk Adjusted ROA, ROE- Return on Equity, RAROE-Risk Adjusted ROE, PPE-Profit per Employee, NPA- 
Non-Performing Assets, CDR- Credit Deposit Ratio, HHI-Herfindahl-Hirschman Index, HII $($ for NII \& II $)=\operatorname{Div}=1-\left[(\mathrm{II} / \mathrm{TI})^{\wedge} 2+(\mathrm{NII} / \mathrm{TI})^{\wedge} 2\right]$

\section{SUMMARY, OBSERVATION \& RESEARCH GAP}

In a nutshell, net interest income is still banks' main income source, providing stability to their earnings. Though, non-interest income source can help banks in supporting their earnings. This is mainly the case when non-interest source of income and main traditional bank activity are negatively correlated.

Following the financial sector reforms, deregulation, technological advancements and globalisation of markets and economies. There is a lot of research that has been done in the area of Diversification in the developed countries but very less research has been done in the developing countries. Mainly because in the developing countries the Diversification was not prominent (Table 2). Nevertheless, this has been slowly changing in the past decade and the proportion of non-interest income in operating income, has been gradually growing in developing economies. (Table 2)

There are academic studies to see the impact of increased income diversification on performance of banks. We come to know that large banks in general are more diversified than small banks with traditional business strategies (Table 2). But the results of the studies are contradictory, about association of non-interest income with financial performance of Banks for studies in different countries and for studies under different time period or type of Bank even when the Banking sector belongs to the same country.

Based on the review of literature, we conclude the following:

- Diversification can be achieved by rebalancing sources of income, geographical boundaries, and sectors.

- Income diversification has a positive relationship with risk adjusted returns and it increased with higher diversification, predominantly in the case of large banks.

- Income diversification on banks financial performance differs based on the economies where the banks are situated.

- Income Diversification levels of Indian Banks is comparatively lower than Global standards.

- We can say that Income Diversification may increase the Bank Performance but the type or proportion of Non-Interest Income coming from trading Activities or Fee Income etc also matters, as it may increases/decreases the stability in return.

- Also there has to be a right balance of Interest and Non-Interest Income. As it follows an inverted U shape. (Vidyarthi, 2019)

- Substantial economic difference between the branches at various geographical locations and the bank with higher diversification showed higher risk-adjusted performance.

\section{CONCLUSION}

After reviewing the various available literature and understanding the findings the paper identifies the following research gap:

- There is need for future research, particularly in the context of developing countries, with regard influence of diversification on performance.

- There is a need for segregating the Banks based on Ownership, Auditors of the bank etc. to see if any of these grouping of the Banks, is a cause for change in the results, due to Diversification. 
- We need to explore the impact of higher non-interest income on the stability of income, profitability and efficiency, mainly in Indian context.

Could diversification reduce issue of cyclical variation in bank profits and revenue.

Table 2 Indian Banking Industry - Non-Interest Income as a percent of Total Income

\begin{tabular}{|c|ccc|ccc|}
\hline \multicolumn{7}{|c|}{ Non-Interst Income / Total Income } \\
\hline \multirow{2}{*}{ Year } & \multicolumn{3}{|c|}{ Private Sector Banks } & \multicolumn{3}{c|}{ Public Sector Banks } \\
\cline { 2 - 7 } & Large & Small & Total & Large & Small & Total \\
\hline 2018 & $19 \%$ & $12 \%$ & $18 \%$ & $15 \%$ & $13 \%$ & $15 \%$ \\
\hline 2017 & $20 \%$ & $12 \%$ & $19 \%$ & $15 \%$ & $12 \%$ & $14 \%$ \\
\hline 2016 & $18 \%$ & $10 \%$ & $17 \%$ & $11 \%$ & $8 \%$ & $11 \%$ \\
\hline 2015 & $18 \%$ & $10 \%$ & $17 \%$ & $10 \%$ & $8 \%$ & $10 \%$ \\
\hline 2014 & $18 \%$ & $9 \%$ & $16 \%$ & $10 \%$ & $8 \%$ & $10 \%$ \\
\hline 2013 & $17 \%$ & $9 \%$ & $15 \%$ & $10 \%$ & $8 \%$ & $9 \%$ \\
\hline 2012 & $18 \%$ & $9 \%$ & $16 \%$ & $10 \%$ & $7 \%$ & $9 \%$ \\
\hline 2011 & $20 \%$ & $10 \%$ & $18 \%$ & $12 \%$ & $9 \%$ & $12 \%$ \\
\hline 2010 & $22 \%$ & $13 \%$ & $20 \%$ & $14 \%$ & $11 \%$ & $14 \%$ \\
\hline 2009 & $19 \%$ & $12 \%$ & $17 \%$ & $14 \%$ & $11 \%$ & $14 \%$ \\
\hline 2008 & $21 \%$ & $13 \%$ & $19 \%$ & $14 \%$ & $12 \%$ & $13 \%$ \\
\hline 2007 & $22 \%$ & $12 \%$ & $20 \%$ & $13 \%$ & $11 \%$ & $12 \%$ \\
\hline 2006 & $22 \%$ & $11 \%$ & $19 \%$ & $14 \%$ & $12 \%$ & $14 \%$ \\
\hline 2005 & $23 \%$ & $13 \%$ & $21 \%$ & $17 \%$ & $16 \%$ & $17 \%$ \\
\hline
\end{tabular}

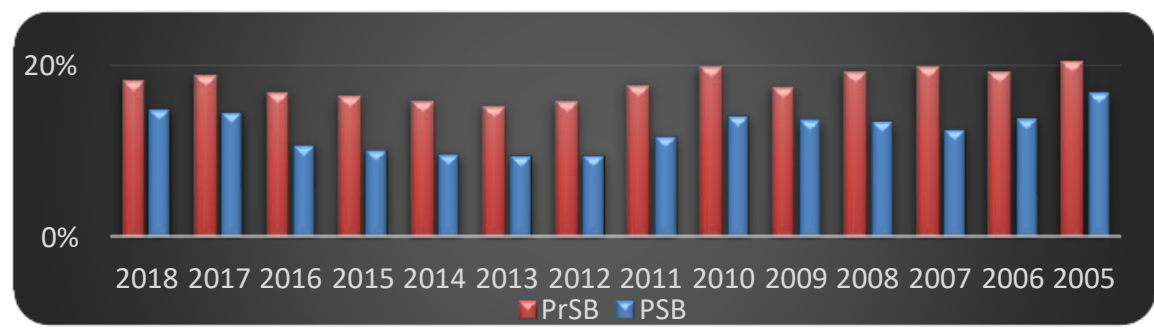

Figure 1 Indian Banking Industry - Non-Interest Income as a percent of Total Income

\section{REFERENCES}

[1] Acharya, V. H., \& Saunders, A. (2006). Should banks be diversified? Evidence from individual bank loan portfolios. Journal of Business, 79, 1355-1412.

[2] Alessandrini, P. C., \& Zazzaro, A. (2005). The geography of banking power: the role of functional distance. BNL Quaterly Review.

[3] Altunbas, Y. M.-I. (2011). Bank Risk During the Financial Crisis - Do Business Models Matter? ECB Working Paper Series, No. 1394, European Central Bank, Frankfurt.

[4] Baele, L., de, J. O., \& Vennet, R. V. (2007). Does the Stock Market Value Bank Diversification? Journal of Banking and Finance.

[5] Bandelj, A. (2016). Should banks be geographically diversified? Empirical evidence from crosscountry diversification of European Banks. The European Journal of Finance.

[6] Bapat, D. (2012). Efficiency for Indian public sector and private sector banks: Assessment of impact of global financial crisis. International Journal of Business Performance Management, $13(3 / 4), 330-40$.

[7] Bapat, D., \& Sagar, M. (2016). Examining Relationship of Income Diversification, Asset Quality with Bank Profitability: Implication for Indian Banks. IMJ.

[8] Bebczuk, R., \& Galindo, A. (2011). Financial crisis and sectoral diversification of Argentine banks. Applied Financial Economics. 
[9] Berger, A. N. (2010). The effects of focus versus diversification on bank performance: Evidence from Chinese banks. Journal of Banking \& Finance.

[10] Berger, N., \& Deyoung, R. (2001). The effects of geographic expansion on bank efficiency. Journal of Financial Services Research.

[11] Bhattacharya, M., \& Dutta, P. (2016). The Performance of Regional Rural Banks and NonBanking Institutions in Priority Sector Lending:. IUP.

[12] Bodnar, G. T. (1999). Both sides of corporate diversification: The value impacts of geographic and industrial diversification. John Hopkins University.

[13] Busch, R., \& Kick, T. (2009). Income Diversification in the German Banking Industry. Bundesbank Discussion Paper, No. 09/2009.

[14] Chen, Wei, Zhang, \& Shi. (2013). Sectoral Diversification and the Banks' Return and Risk: Evidence from Chinese Listed Commercial Banks. Procedia Computer Science.

[15] Chiorazzo, V., Milani, C., \& Salvini, F. (2008). Income Diversification and bank performance: Evidence from Italian banks. Journal of Financial Services Research, 33(3), 181-203.

[16] Choi, S., \& Kotrozo, J. (2006). Diversification, Bank Risk and Performance: A Cross-Country Comparison. SSRN Electronic Journal, 10.2139. 1013430.

[17] Cotugno, M., \& Stefanelli, V. (2010). Bank intermediation models and portfolio default rates. What's the relation? 23rd Australasian Banking and Finance Conference.

[18] Davis, P. E. (2000). The changing structure of banks' income - an empirical investigation.

[19] De Young, R., \& Rice, T. (2004). Non-interest income and financial performance at US commercial banks. The Financial Review, 39, 101-127.

[20] Deb, J., \& Sen, G. (2016). Geographic Diversification in Indian Banking: Assessing the Impact on Risk and Returns. The IUP Journal of Bank Management.

[21] Demirgüc-Kunt, A. a. (2010). Bank Activity and Funding Strategies: The Impact on Risk and Returns. Journal of Financial Economics, Vol. 98.

[22] Deng, S. (., \& Elyasiani, E. (2008). Geographic diversification, bank holding company value and Risk. Journal of Money, Credit and Banking.

[23] DeYoung, R., \& Roland, K. P. (2001). Product mix and earning volatility at commercial banks: evidence from a degree of total leverage model. Journal of Financial Intermediation, 10, 54-84.

[24] Diamond, D. W. (1984). Financial intermediation and delegated monitoring. The Review of Economic Studies.

[25] Feldman, R., \& Schmidt, J. (1999). Non-interest income: A potential for profits, risk reduction and some exaggerated claims. Fedgazette.

[26] Gallo, J., Apilado, V., \& Kolari, J. (1996). Commercial bank mutual fund activities: Implications for bank risk and profitability. Journal of Banking \& Finance.

[27] Gambacorta, L. S. (2014). Diversification and bank Profitability: A nonlinear approach. Applied Economics Letters.

[28] García-Herrero, A., \& Vázquez, F. (2013). International diversification gains and home bias in banking. Journal of Banking and Finance.

[29] Ghosh, S. (2011). Diversification and Firm Value: Evidence from Indian Banks. South Asian Journal of Management, 18. 7-25.

[30] Gupta, M., \& Singh, J. (2014). Extent of Income Diversification in Indian Banks and whether Non-Interest Income is a stable source of Income for them. International Journal of Economic Issues, Vol. 7, No. 1, 123-143. 
[31] Harris, M. K. (1982). Asymmetric information, incentives and intra-firm resource allocation. Management Science.

[32] Hayden, E., Porath, D., \& Westernhagen, N. (2007). Does diversification improve the performance of German banks? Evidence from individual bank loan portfolios. Journal of Financial Services Research, 32(3), 123-140.

[33] Hirtle, B., \& Stiroh, K. (2007). The return to retail and the performance of US Banks. Journal of Banking and Finance.

[34] Iskandar-Datta, M., \& McLaughlin, R. (2007). Global diversification: new evidence from corporate operating performance. Corporate Ownership and Control.

[35] Khandelwal, A. K. (2006). Universal banking: Solution for India's financial challenges. Economic and Political Weekly.

[36] Köhler, M. (2012). Which Banks are More Risky? The Impact of Loan Growth and Business Model on Bank Risk-Taking? Discussion Paper, Deutsche Bundes bank, No. 33/2012.

[37] Köhler, M. (2013). Does non-interest income make banks more risky? Retail-versus investmentoriented banks. Discussion Paper Deutsche Bundesbank, No 17/2013.

[38] Kwast, M. (1989). The impact of underwriting and dealing on bank returns and risks. Journal of Banking \& Finance, 2, 18- 31.

[39] Langrin, R. B. (2009). Measuring the effects of concentration and risk on bank returns: evidence from a panel of individual loan portfolios in Jamaica. Journal of Business Finance \& Economics in Emerging Economies.

[40] Lepetit, L., Nys, E., Rous, P., \& Tarazi, A. (2007). Bank income structure and risk: An empirical analysis of European banks. Journal of Banking and Finance.

[41] Limei Sun, S., Zhu, Z., \& Stephenson, A. (2017). Noninterest Income and Performance of Commercial Banking in China. Scientific Programming.

[42] Markowitz, H. (1952). PORTFOLIO SELECTION. Journal of Finance.

[43] Markowitz, H. (1959). Portfolio Selection:Efficient Diversification of Investments. New York: John Wiley.

[44] Meyer, M. M. (1992). Organizational Prospects, Influence Costs and Ownership Changes. Journal of Economics and Management Strategy.

[45] Miller, S., \& Parkhe, A. (2002). Is there a liability of foreignness in global banking? An empirical test of Banks, x-efficiency. Strategic Management Journal.

[46] Morgan, D., \& Samolyk, K. (2003). Geographic diversification in banking and its implications for bank portfolio choice and performance. Federal Reserve Bank of New York.

[47] Morris, J. (2001). Risk diversification in the credit portfolio: an overview of country practices. IMF Working Paper WP-01—200, International Monetary Fund.

[48] Pennathur, Subrahmanyam, V., \& Vishwasrao. (2012). Income diversification and risk: Does ownership matter? An empirical examination of Indian banks. Journal of Banking \& Finance.

[49] Rajan, R. S. (2000). The cost of diversity: The diversification discount and inefficient investment. The Journal of Finance.

[50] RBI. (2018). Retrieved from rbi.org.in: https://m.rbi.org.in/scripts/FAQView.aspx?Id=87

[51] Rebello, B. J. (2016, August 29). The Economic Times. Retrieved from The Economic Times: https://economictimes.indiatimes.com/industry/banking/finance/banking/private-sector-banksexceed-priority-sector-target-foreign-banks-lag/articleshow/53912839.cms?from=mdr

[52] Rossi, S. S. (2009). How loan portfolio diversification affects risk, efficiency and capitalization: A managerial behavior model for Austrian banks. Journal of Banking \& Finance. 
[53] Shameem, J. M., Kumar, T. S., Subhash, D. A., \& Vinod, T. A. (2015). Investigating The Effects Of Sectoral Diversification Of Loan And Advances On Risk And Return Of Indian Commercial Banks: Post - Financial Crisis Of 2008. Smart Journal of Business Management Studies.

[54] Sharma, S., \& Anand. (2017). Does diversification of income source influences bank' s riskreturn characteristics? Evidence from the Indian market. International Journal of Indian Culture and Business Management Indian Culture and Business Management.

[55] Sharma, S., \& Anand. (2018). Income diversification and bank performance: evidence from BRICS nations. International Journal of Productivity and Performance Management.

[56] Sharma, S., \& Anand, A. (2019). Geographical diversification and bank performance: evidence from Indian Banks. International Journal of Productivity and Performance Management.

[57] Shawn, T. (2002). Firm Diversification and Asymmetric Information: Evidence from Analysts' Forecast and Earnings Announcements. Journal of Financial Economics, pp 373-396.

[58] Smith, R. C. (2003). Non-interest income and total income stability. Bank of England, , Working Paper No. 198.

[59] Stein, J. C. (1999). Internal capital markets and the competition for corporate resources. Journal of Finance.

[60] Stiroh, K. J. (2004a). Diversification and Banking: Is Non-interest Income the Answer? Journal of Money, Credit, and Banking, 36, 5, 853-882.

[61] Stiroh, K., \& Rumble, A. (2006). The dark side of diversification: The case of USA financial Holding companies. Journal of Banking and Finance.

[62] Tabak, B. M., Fazio, D. M., \& Cajueiro, D. O. (2011). The effects of loan portfolio concentration on Brazilian banks' return and risk. Journal of Banking \& Finance.

[63] Teece, D. (1982). Towards an economic theory of the multiproduct firm. Journal of Economic Behavior \& Organization.

[64] Vidyarthi, H. (2019). Dynamics of Income Diversification and Bank Performance in India. Journal of Financial Economic Policy.

[65] Wall, L. (1987). Has bank holding companies' diversification affected their risk of failure? . Journal of Economics and Business. 